\title{
CHILDREN'S EDUCATION IN THE FAMILY IN TERMS OF AL-QUR'AN, LETTER LUQMAN VERSE 12-19 STUDY OF AL-AZHAR INTERPRETATION
}

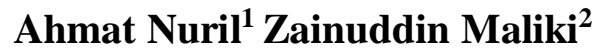 \\ ahmat.nuril@gmail.com¹ zainuddin_M@gmail.com²
}

\begin{abstract}
This study aims to find out and describe children's education in the family in terms of al-Qur'an, letter Luqman verse 12-19 study of al-Azhar interpretation. This research is a type of qualitative descriptive research. Data collection techniques in this study use library research methods. While data analysis techniques are used with the tahlili method and content analysis method. The results of the study show that the main points of children's education in the family are contained in the verses of the Luqman verse 12-19 as follows: 1). Aqidah education is the command to purify monotheism to Allah SWT, 2). The worship education is the command to uphold five times prayer in congregation and sunnah prayer, 3). Muamalah education is doing good and preventing evil, 4). Moral education includes; give thanks to Allah SWT, devote to parents, be gentle, be patient, charity sincerely because of Allah SWT, be polite, be a noble character, prohibition to be arrogant, prohibition of pride, be good when walking, prohibition of hardening when speaking, and prohibition on rebuking.
\end{abstract}

Keywords: Child, family education, Q.S. Luqman Verses 12-19, interpretation meaning of al-Azhar

\section{A. Background}

As the development of the information technology and globalization in the modern era, it turns out that on the other hand it raises problems and problems that are often found in individuals in a group or society. The rise of juvenile delinquency, drug abuse (NAPZA), sexual deviation, and psychiatric disorders is a form of the negative impact of the progress of civilization.

As the example to the case; first drug abuse (NAPZA). BNN recorded the number of students who use drugs in the city of Surabaya in January-November 2016 as many as 
200 students. This number skyrocketed compared to 2015. To suppress and prevent the growth of drug users at the level of students, municipal government and BNN Surabaya City held urine tests at Kartini Middle School and Vocational high School, Simogunung Barat Tol I area, Thursday (1/12/2016). The results are astonishing, the urine of five students in Surabaya is positive for drugs. Urine tests at two schools in one complex were randomly conducted, 108 selected junior and vocational high school students. They consist of 4 vocational school and junior high school students that have positive. Secondly the death-ended persecution was carried out by a student of SMAN 1 Torjun, HI (170 to his teacher, Ahmad Budi Cahyono (26). The third, Tulungagung people, East Java were shocked by the news of elementary students, HE (14) impregnating junior high school students, DE (16) to 6 months pregnant.

The cases that occur above are some indicators of moral and personality degradation in children. In order for these conditions not to be more alarming, the role of both parents is needed to keep and maintain, ${ }^{1}$ educate and develop their children's potential in accordance with the nature they have. Because children are a gift ${ }^{2}$ and trust $^{3}$ given by Allah SWT. Besides that, the child is also a descendant (dzuriyah) ${ }^{4}$.

Educating children includes many things ranging from physical development, health, skills, thoughts, feelings, willingness, social, even to the development of faith. ${ }^{5}$ The growth of the potential of the child, both the bad personality and morals are determined by both parents in providing education and guidance. Because parents are the first and foremost educators in the family environment. As the hadiths of the Prophet Muhammad were as follows; From Abu Hurairah ra. He said the Messenger of Allah said: "No one is a newborn child but he is clean (fitrah). Both parents made him become a Jew, Christian, or Magi. "Then he said," Read the verse: "... the nature of God who created man according to the nature; there is no change in the nature of God, that is righteous religion ... "(Ar-Rum30: 30) (H.R Muslim: 2283)6

\footnotetext{
${ }^{1}$ QS. 66 Ath-Tahrim: 6.

${ }^{2}$ QS.25 Al Furqon: 74.

${ }^{3}$ QS.8 Al-Anfal: 27.

${ }^{4}$ QS. 3 Ali Imran: 38.

${ }^{5}$ Made Pidarta, Landasan kependidikan, Stimulus Ilmu Pendidikan bercorak Indonesia Edisi III (Jakarta: Rineka Cipta, 2013), 2.

${ }^{6}$ Al-Imam Muslim, Terjemahan Hadis Shahih Muslim, Jilid I, II, III \& IV (Kuala Lumpur: Klang Book Centre, 2007), Jilid IV, 242.
} 
Child education is a very important matter in Islam. In the Koran we find how Allah SWT narrates Luqman al-Hakim's advice which is a form of education for his children. Likewise, in the hadiths of the Prophet SAW, we also find many forms of education for children, both from the orders and the actions of the children directly educating children. Therefore, parents must be smart and precise in providing the love needed by their children. If the educator in this case is the parent does not educate and nurture the child eventually the child will fall into disrepute, then parents will also receive the consequences of both life in the world and the hereafter.

Good family education is one that wants to give strong encouragement to their children to get religious education. Education in the family has a positive influence in which the family environment encourages or provides motivation and stimulation to the child to receive, understand, believe and practice the teachings of Islam. ${ }^{7}$

\section{B. RESEARCH METHOD}

This research is a type of qualitative descriptive research. In this qualitative descriptive study there are attempts to describe, record, analyze and interpret conditions that currently occur or exist. In other words, this qualitative descriptive study aims to obtain information about the existing situation. ${ }^{8}$ In this study, researchers tried to find out and describe about children's education in the family in terms of al-Qur'an letter Luqman verse 12-19 in interpretation meanging of al-Azhar.

Data collection techniques in this study use library research method, so the steps taken are to read, understand and study books, both in the form of interpretation books and other sources relating to the existing problems and then analyzed.

The data analysis technique in this study uses the tahlili method and (content analysis method), which is as follows:

a. Tahlili Metode

According to Nashrudin Baidan, the method of tahlili interpretation is to interpret the verses of the Koran by describing all aspects contained in the interpreted verses

\footnotetext{
${ }^{7}$ Mansur, Pendidikan Anak Usia Dini dalam Islam (Yogyakarta: Pustaka Pelajar, 2009), 318 - 319.

${ }^{8}$ Mardalis, Metode Penelitian Suatu Pendekatan Proposal (Jakarta: Bumi Aksara, 1999), 26.
} 
and explaining the meanings included in it according to the expertise and inclination of the interpreters who interpret the verses. ${ }^{9}$

b. Content Analisis Metode

In order to get answers to existing problems, the author uses the method of content analysis. According to B. Berelson as quoted by Hasan Sadily, the method of Content Analysis is an inquiry technique that attempts to describe objectively, systematically and quantitatively the content manifested in a communication. ${ }^{10}$

\section{RESEARCH RESULT AND DISCUSSION}

The main points of Islamic education contained in the Qur'an of Luqman verses 12-19 are as follows:

\section{Give thanks to Allah SWT}

The word gratitude is taken from Arabic, namely the word syakara, syukuran, In the Big Indonesian Dictionary, gratitude means 1) gratitude to God; 2) fortunately (relief, pleasure, etc. $)^{11}$

A person who is grateful is that people thank to Allah for all forms of blessings that are given to him, either by mentioning these favors or by using them in the way He wishes. Buya Hamka explained in his interpretation that human mind is too low if he does not know that his whole life is covered by the blessings of Allah SWT.

According to Prof. Zainudin Ali MA, thankful that human express gratitude to God for the blessings that have been obtained by him. The expression of gratitude in question appears through words and deeds. The expression of gratitude in the form of words is saying Alhamdulillah (all praise to Allah) at all times. While giving thanks through deeds is to use God's favor according to His pleasure. ${ }^{12}$

As a person who is aware of his position, then always be grateful for all forms of enjoyment that God has bestowed upon him. Various kinds of favors and blessings given

\footnotetext{
${ }^{9}$ Nashruddin, Baidan, Metodologi Penafsiran al-Qur'an (Yogyakarta: Pustaka Pelajar, 2000), 31.

${ }^{10}$ Hasan Sadily, Ensiklopedia (Jakarta: Ikhtiar Baru Van Hoeva, 1980), 207.

${ }^{11}$ Adang Hambali, dkk., "Faktor-Faktor yang Berperan dalam Kebersyukuran (Gratitude) pada Orangtua Anak Berkebutuhan Khusus Perspektif Psikologi Islam”, Psympathic, Jurnal Ilmiah Psikologi Vol. 2, No. 1 (Juni 2015), 94.

12 Zainuddin Ali, Pendidikan Agama Islam (Jakarta: Bumi Askara, 2015), 33.
} 
by Allah SWT, then we cannot count how many, ${ }^{13}$ since man was born into the world until he lived life, until he was put into the earth.

\section{2. purify the bassic ideology to Allah SWT}

Akidah in Arabic is aqidah. Etymologically the aqeed is bond and / or hook. Whereas in the terminology of the faith is faith, beliefs that hold life for every adherent of Islam. ${ }^{14}$ In particular the faith contains the meaning of the pillars of faith which contains beliefs in: 1) Allah, 2) His Angel, 3) His book, 4) His apostles, 5) the final day and 6) qada and qodar. Therefore, the pillars of faith (arkanul al-iman) are principles for Islamic teachings.

Islam is the religion of monotheism which means the belief in the oneness of God which in the teachings of Islam is called Allah. Tawhid is a prima causa (the first origin, from everything) of all Islamic beliefs. ${ }^{15}$ Therefore, if someone has accepted monotheism as prima causa, then the points of belief which are called other pillars of faith are a logical result of the acceptance of monotheism.

In principle, every child has fitrah ilahiayah. This fitrah is like a foundation in a building, in the form of a spirit that tends to know its God. With that nature, humans actually have a tendency to religion, an absolute tendency to good behavior. If fitrah is analogous to a foundation, the building (human) that stands on the foundation should be the best building. ${ }^{16}$ In line with what Harry Santosa said that every child born in a state has installed the potential nature of faith that is testifying that God is Rabb (kholiqan, raziqan, malikan). ${ }^{17}$

Therefore, as parents, they should instill and nurture their children's souls about the purification of monotheism to Allah SWT. As Luqman taught his child that the main guideline in life is not to associate another God with Allah SWT. Because there is no God but Allah. Even what is apart from God is mere nature, the creation of Allah SWT. It is not that God is allied or shares with another God in creating this world. ${ }^{18}$

\footnotetext{
${ }^{13}$ Al-Qur'an, 16 An-Nahl:18

${ }^{14}$ Zainuddin Ali, Pendidikan., 2. Lihat juga Mohammad Daud Ali, Pendidikan Agama Islam (Jakarta: Rajawali Pres, 2010), 199.

${ }^{15}$ Ibid., 2.

${ }^{16}$ Munif Chatib, Orangtuanya manusia (Bandung: Kaifa, 2013), 4.

${ }^{17}$ Harry Santosa, Fitrah Based Education (Bekasi: Yayasan Cahaya Mutiara Timur, 2017), 42.

${ }^{18}$ Hamka, Tafsir., 97.
} 
If human beings have been caring for others, while others are mere objects or mere beings, humans themselves bring their souls into slavery from others, persecute themselves, fool themselves. According to 'Aidh al Qorni explained that people who actually experience the misery, pain, humiliation and anger of Allah SWT are those who are poor in faith and experience a crisis of faith. ${ }^{19}$

Allah SWT says; And whoever turns away from My warning, then surely for a narrow life, and We will gather it on the Day of Judgment blind. ${ }^{20}$

From this verse 'Aidh al Qorni explained that there is nothing that can make the soul happy, cleanse it, and expel anxiety from it other than the true faith in Allah SWT. ${ }^{21}$ Likewise in the interpretation of Ibn Abbas quoted by Buya Hamka that because the idea is always bad and lack of trust in Allah SWT that is what makes him difficult and narrow always. ${ }^{22}$

Furthermore according to Abu Amr Ahmad Sulaiman that for children's education to be able to form a belief and faith in Allah SWT, then there are facilities that help parents, such as: Reciting Laa ilaaha illallah and repeating it, deepening muraqabah of Allah SWT in his heart, deepening the love for The Messenger of Allah in his heart by carrying out his Sunnah and following him, and giving gifts to children at certain times, such as gifts for memorization of the Qur'an and recitation of prayers continuously. ${ }^{23}$

\section{Be good to both parents}

Allah Almighty said: And We have made a statement to mankind towards both his mother and father. His mother had conceived him in a bad state and he was getting worse and caring for him in two years. That you thank God and your parents; I am the place again. ${ }^{24}$

In this verse the value of education contained in it is the command of Allah SWT to humans so that they respect and glorify the two mothers of their fathers.

\footnotetext{
19 'Aidh al-Qorni, La Tahzan, Jangan Bersedih (Jakarta: Qisthi Press, 2004), 26.

${ }^{20}$ Al-Qur'an, 20 Thaha, 124.

21 'Aidh al-Qorni, La Tahzan., 26.

${ }^{22}$ Hamka, Tafsir Al-Azhar Jilid 5 (Jakarta: Gema Insani, 2015), 621.

${ }^{23}$ Abu Amr Ahmad Sulaiman, Panduan Mendidik Anak Muslim Usia Pra Sekolah (Jakarta: Darul Haq, 2013), 5.

${ }^{24}$ Al-Qur'an, 31 Luqman: 14.
} 
Father and mother are the people who have the most kindness to children. ${ }^{25}$ Because by going through the path of the two mothers, you are born into the earth.

How bad mother is pregnant, poorly getting worse. Since being pregnant from the first month, it gets worse every month and until the peak of the child is born. Weak throughout the body when the child comes out. Since giving birth and caring, suckling, talking, guarding, maintaining the pain. Since he was still lying on his back, until gradually clever cupping, until it gradually faded, until it gradually crawled, until it hung gradually walked, bersiansur, upright and fell and upright, until it did not fall again. Within two years.

Therefore, Allah SWT obliges humans to do good to their mothers. ${ }^{26}$ Because Allah SWT knows that old people are willing to work hard in their lives, nothing but for the sake of their children. They feel bad, tired and sick during pregnancy, childbirth, and breastfeeding. He was the one who had tears in his cheeks when he found out his son had fallen ill. So, with all the effort he tried hard to heal his child.

Likewise, the father defends and protects the mother and protects her children. The father who tried to find clothing and food every day worked hard, slamming the glory of the lives of his young children.

As contained in the Prophet's hadith: A man came to meet the Messenger of Allah and asked, "O Messenger of Allah who is the one I have the most right to treat well?" He replied, "Your mother." He asked again, Then who else? Then who else? The man continued. Your mother, replied the Prophet. The man asked again, then who else? "The Messenger of Allah said," your father ". (HR. Mutafaqun 'Alaih)

After knowing so much the sacrifice of parents towards their children, it is appropriate and is a necessity to glorify it.

According to Hamid Ahmad, Thahir explained the rights of both parents, ${ }^{27}$ including:

1. Observe both when young or old.

\footnotetext{
${ }^{25}$ Majelis Tarjih Pimpinan Pusat Muhammadiyah, Risalah Islamiyah Bidang Akhlak (Yogyakarta: Suara Muhammadiyah, 2012), 61.

${ }^{26}$ Al-Qur'an, Al-'Ankabut:8

${ }^{27}$ Hamid Ahmad ath-Thahir, Akhlak islami si buah hati: Pendidikan akhlak ala Nabi (Solo: Pustaka Arofah, 2006), 25.
} 
2. Do good to both.

3. Glorify both, kissing both hands and respecting both.

4. Not burdens with both demand and guidance.

5. Take precedence over the mother and father of everyone. So when a Muslim wants to give a gift, it is best to put his parents first.

6. Encourage them both to receive God's mercy and forgiveness and to invoke men to pray for their parents.

7. It does not reveal the dislike of both with the word "uf '(ah) which consists of only two letters.

8. Summoning "father" and "mother" Do not imitate the culture of people who call their parents in the name of "hi fulan" and "hi fulanah", because it is a bad manner to them.

9. Maximizing respect for both

10. Always strive to gain the pleasure of both of them, and not make them both angry.

\section{Gentleness and compassion}

Gentleness and compassion are the two qualities that are called for in Islam and ordered by the Prophet Muhammad. Merciful man is a human whose heart is gentle who always does good. Prophet Muhammad SAW said "Verily Allah is all soft and likes tenderness in every matter" H.R. Mutafaqun aih alaih). Gentleness is a high quality that only believers have. ${ }^{28}$

Relationships in the family must always be fostered as well as possible, with mutual respect or respect. The younger must respect the older, and the older must respect the younger. Do not mock or insult each other, and if there is a dispute, it should be held immediately. ${ }^{29}$

\section{Doing Sholat (pray)}

\footnotetext{
${ }^{28}$ Al-Qur'an, 3 Ali Imran: 159.

${ }^{29}$ Majelis Tarjih Pimpinan Pusat Muhammadiyah, Risalah Islamiyah Bidang Akhlak (Yogyakarta: Suara Muhammadiyah, 2012), 67.
} 
Allah SWT said: O my son! Establish prayers and tell them to do what is good and prevent doing what is wrong and be patient for whatever happens to you. In fact such things are as important as work. ${ }^{30}$

In this paragraph there are 4 education subjects including; prayer and amar ma'ruf, nahi mungkar and patience. But in this sub-chapter is focused on the first point, namely the discussion of prayer. Prayers in Arabic: prayer. In terms of syara 'is worship done to prove devotion and humility to Allah SWT. ${ }^{31}$ Establishing Prayers is to fulfill them regularly, by completing the conditions, pillars and manners, whether born or inward, like special, paying attention to what is read and so on.

Prayer is the pillar of Religion. ${ }^{32}$ Allah SWT created man in perfect and noble form. To strengthen the person and strengthen the relationship with Allah SWT, to deepen gratitude to Allah SWT for His blessings and protection that we always receive, establish prayer. With prayer we train the tongue, the heart and all the limbs always remember God. In our religion Islam has determined that we are obliged to pray for at least five times a day a night. Don't be more or less allowed! Besides that, by praying, a person will be spared from cruel and evil acts. ${ }^{33}$

We can calculate by ourselves how much the impression is to the soul that the name of Allah SWT is always the designation, Allahu Akbar, Alhamdulillah, subhanallah, by bowing when bowing, by breaking the forehead when prostrating, straight upright not swinging left and right, we will get personal, birth and inner strength, moral and material.

Allah SWT said: And establish prayer, give zakat and ruku "it is with those who bow" ${ }^{34}$ It is clear, that congregational prayer is 27 times the reward of prayer itself. Even among the ulama, as Imam Ahmad bin Hambal, said that prayer is obligatory in congregation, even though only two people. According to Imam Abu Hanifah, the mosque should pray at the mosque. The lesson is that individuals do not get out of society, or for themselves in society.

\footnotetext{
${ }^{30}$ Al-Qur'an, 31 Luqman: 17.

${ }^{31}$ Deden Suparman,"Pembelajaran ibadah shalat dalam perpektif Psikis dan medis, Fakultas Sains dan

Teknologi, ISSN 1979-8911, Volume IX No. 2 (Juli 2015), 51.

${ }^{32}$ Hamka, Tafsir al-Azhar Jilid 7 (Jakarta: Gema Insani, 2015), 103.

${ }^{33}$ Al-Qur'an, 29 Al Ankabut: 45.

${ }^{34}$ Al-Qur'an, 2 Al Baqarah: 43.
} 
Shaykh Mustafa al-Adawi explained the teaching taught by parents to children in order to establish prayers including: ${ }^{35}$

1. A father should encourage his child to pray, practice it, and introduce the houses of God, and invite him there if the child (can be ascertained) does not make damage in it.

2. Teach that prayer is light and prayer can prevent evil and evil.

3. Teach the child that prayer is a pillar of Islam and a pillar of religion, and that the five daily prayers can eliminate sin. As Allah says in the Qur'an the letter Hud verse 114.

4. Explain to children about sin if they leave prayer. As in the Al-Qur'an, AlMuddatsir: 38-46.

5. Teach adab and sunnah in performing prayers such as setting shaf. Explain to the child that the adult's shaf in front and the children in the back in a good and polite manner, do not bother and make the child go away.

6. Teach the children the wisdom of why the child's shaf is behind.

\section{Commanding to the good and stopping to the bad}

Islamic teachings develop the teachings of the mission which requires da'wah to the people to spread the spread of religion, both individually and in groups. In the alQur'an, the term amar ma'rūf nahi munkar, is mentioned repeatedly 9 times in a different letter, but is referred to as a whole. While the word ma'rūf stands alone is 39 times in a different letter. ${ }^{36}$

Ma'ruf is a good deed accepted by the community. Try to be a pioneer of that meaningful act. People who have been firmly determined by their worship, especially prayer, he will dare to convey the truth to his fellow human beings, just the knowledge and abilities that he has. At least tell the child and wife to pray.

After that, you should also dare to rebuke where the wrong thing is, which cannot be accepted by the community. Dare to say the right, though bitter. Just keep wisdom. That is, wrap a bitter kinine medicine with sugar, to get rid of the esophagus.

\footnotetext{
${ }^{35}$ Syaikh Mustofa al Adawi, Tarbiyatul Abna'., 218.

${ }^{36}$ Kusnadi, "Makna Amar Ma'ruf Nahi Munkar Menurut Muhammad Asad Dalam Kitab The Message Of The Qur'an”, Wardah, vol.18, no.2, (2017), 97.
} 


\section{Be patient}

Etymologically the patient comes from the Arabic language, صبر ا - بصبر - صبر which means to be patient, steadfast, brave. ${ }^{37}$ According to Yunahar Ilyas, patience means restraining and restraining. ${ }^{38}$ Whereas in Indonesian, patience means: "withstand trials, steadfast, calm, unhurried, not in a hurry of lust. ${ }^{39}$ In terminology what is meant by patience is not to complain or complain to other than Allah SWT about the suffering that befell him. ${ }^{40}$

The word patience in the al-Qur'an is not less than 90 places. ${ }^{41}$ Only patiently one can achieve what is meant. Only patiently one can achieve the degree of faith in the struggle. Just patiently convey advice to negligent people. Only patiently the truth can be established. ${ }^{42}$

Patience is part of the al-karimah morality needed by a Muslim in world and religious matters. ${ }^{43}$ As Muslims, of course it is obligatory to use his heart to take care of all the tests and suffering calmly. A patient who is patient will not complain in the face of all the hardships that befall him and will not become weak or fall because of the calamities and disasters that plague him. Allah Almighty has committed patience to him and taught that whatever happens to him in the life of the world is only a trial from Him to be known to those who are patient.

If you have the courage to admonish what is wrong, prevent the wrong, it must be known that there will be people who are not happy to be rebuked. Or improve the community that has frozen with the wrong customs. If they reprimand them, they must be steadfast, must be patient. Because whatever is the field of life that we enter, if we are impatient, we will break in the middle of the road. Remember that so many Apostles

\footnotetext{
${ }^{37}$ Mahmud Yunus, kamus Arab- Indonesia (Jakarta: Yayasan penyelenggara penterjemah/ penafsiran alQur'an, 1973), 211.

${ }^{38}$ Yunahar Ilyas, Kuliah Akhlak, cet.1 (Yogyakarta: LPPI, 1999), 134.

${ }^{39}$ Depdikbud, Kamus Besar Bahasa Indonesia, cet ke 3 (Jakarta: Balai Pustaka, 1990), 763.

${ }^{40}$ Majelis Tarjih Pimpinan Pusat Muhammadiyah, Risalah Islamiyah Bidang Akhlak (Yogyakarta: Suara Muhammadiyah, 2012), 47.

${ }^{41}$ Ibid., 47.

${ }^{42}$ Hamka, Tafsir al-Azhar juz 2 (Jakarta: Pustaka Panjimas, 1983), 21.

${ }^{43}$ Hamka, Tafsir al-Azhar juz 2 (Jakarta: Pustaka Panjimas, 1983), 21.
} 
sent by Allah SWT gave guidance to humans, all were hurt by their people. Their main capital is patience.

\section{Prohibition to be an arrogant and cruel}

Arrogant is raising or boasting and underestimating others. ${ }^{44}$ According to Shodiq Abdullah as quoted by Munif Chatib that pride is interpreted to feel or consider themselves big and high because of the goodness or perfection of him, whether property, knowledge or anything else. ${ }^{45}$ Arrogant is a great attitude and likes to think of others as trivial, feeling himself big, feeling himself smart and tall in all things, both property, spouse and position ${ }^{46}$

a. The refference not to be arrogant

Allah Almighty said: "Thou shalt not raise your face from men, and do not walk on the face of the earth with pride. Verily Allah does not like every arrogant pride. ${ }^{47}$

This includes the highest manners, manners and morals. That is if you're talking to someone face to face, face you to him. Confronting the face is a sign of facing the heart. Listen to him talk, watch carefully. If you talk to someone, even though you face it in another direction, you will feel offended. He is not appreciated his words are not perfectly heard.

In greeting, I first met, how could I greet people again and again, when I shook hands, look happily at his eyes. His heart will be great and friendship will be firm. What's more if the name is remembered and called.

Ibn Abbas explained the interpretation of this verse, "Do not be arrogant and despise the servants of God, and do not put your face to another place when talking to him".

Likewise, the interpretation of Ikrimah, Mujahid, Yazid bin al-Asham, and Said bin Jubair. (And do not walk on earth with pride). Lifting yourself up, arrogant, about being rich, about being strong, about being considered a hero, about being high-

\footnotetext{
${ }^{44}$ Majelis Tarjih Pimpinan Pusat Muhammadiyah, Risalah Islamiyah Bidang Akhlak (Yogyakarta: Suara Muhammadiyah, 2012), 59.

${ }^{45}$ Munif Chatib, Orangtuanya., 6.

${ }^{46}$ Sa'id Hawwa, Kajian Lengkap Penyusian Jiwa, Tazkiyatun Nafs, Intisari Ihya 'Ulumuddin (Jakarta:

Pena Pundi Aksara, 2006), 243.

${ }^{47} \mathrm{Al}-\mathrm{Qu}$ 'an, 31 Luqman 18
} 
ranking, and so on. (Verily, Allah does not like every arrogant pride). Arrogant and proud of themselves, all of that according to the investigation of psychology, the publication is from because there is a feeling, that the self is actually not so high in price. Lifted upwards, it is highlighted because in the depths of the soul it feels that the self is indeed low or invisible. He doesn't ask people's attention. Because you feel unnoticed. Assessed in terms of faith, it is obvious that the faith of that person is still flawed.

Allah SWT also said in another verse: There is no doubt that Allah really knows what they keep secret and what they bring forth. Verily Allah does not like arrogant people. $^{48}$

Allah SWT also says in another verse: Surely those who are arrogant of my worship will go to hell Hell in contempt. ${ }^{49}$

b. The action not to be arrogant

The opposite of arrogant attitude is courtesy (tawadhu '). Courtesy (tawadlu ') is an attitude and behavior that shows humility. ${ }^{50}$ It is this attitude which is a commendable attitude, which is one of Rahman's attributes of mercy which God describes in His words, And the merciful servants of God (those) are those who walk on the earth humbly and when the people ignorant greet them, they say the words (which contain) salvation. ${ }^{51}$

The rightful people are called ad Ibadur Rahman (servants of the Most Gracious God), those who walk on the earth of Allah with courtesy, are gentle, not arrogant and not proud. His attitude is calm. ${ }^{52}$

\section{9. be good when walking}

Allah SWT said: And simplify you in walking and soften the voice. Truly the worst sound is the sound of a donkey. ${ }^{53}$

\footnotetext{
${ }^{48}$ Al-Qur'an, 16 An-Nahl: 23.

${ }^{49}$ Al-Qur'an, 40 Ghofir: 60.

${ }^{50}$ Majelis Tarjih Pimpinan Pusat Muhammadiyah, Risalah Islamiyah Bidang Akhlak (Yogyakarta: Suara Muhammadiyah, 2012), 45.

${ }^{51}$ Al-Qur'an, 25 Al-Furqan: 63.

${ }^{52}$ Hamka, Tafsir al-Azhar Jilid 6 (Jakarta: Gema Insani, 2015), 394.

${ }^{53}$ Al-Qur'an, 31 Luqman: 19.
} 
"And simplify in walking". Do not be quick to push, afraid that if you get tired. Don't be slow to stun because it brings laziness and wastes time on the road, be simple. Rasulullah SAW also said as in his hadith: "It is narrated from Sahal bin sa'ad As-Saa'di ra., He said: The Messenger of Allah said:" Hurry is from the devil "(HR. At-tirmidhi, he said this Hadith hasan) ${ }^{54}$

"And soften the sound". Don't make a loud voice not worth the attendance. What more if you hang out with people in public places. The person who did not know courtesy forgot, that in that place he was not alone with his friend who was sitting. Then he made a loud voice.

Every human being, every day, and almost every time, uses and needs communication. One of the communication tools that we use often is spoken language. In using language or talking with the other person, we must use good language, easy to understand and understand. The Prophet has exemplified us. How gentle and polite the Prophet is. So that each of his interlocutors felt he was the most honored by the Prophet.

"Truly the worst sound is the sound of a donkey." Mujahid said, "Indeed, the donkey's voice is very bad. Then the person who made a loud voice, rebuked, until like his throat would burst, his voice turned upside down, resembling the sound of a donkey, not pleasant to hear. And he was not liked by Allah SWT. Therefore, in speaking with the opponent, we must use good karma and speech. Do not let our language hurt others, be stubborn, cheat and cause hostility. Good morals will produce good language.

\section{CONCLUTION}

The results of the study show that the main points of children's education in the family are contained in the verses of the Luqman verse 12-19 as follows: 1). Aqidah education is the command to purify monotheism to Allah SWT, 2). Worship Education is the command to establish five times prayer in congregation and sunnah prayer, 3). Muamalah education is doing good and preventing evil, 4). Moral education includes; give thanks to Allah SWT, devote to parents, be gentle, be patient, charity sincerely because Allah SWT, polite satun, noble character, prohibition of pride, ban on arrogance,

\footnotetext{
${ }^{54}$ Al-Hafizh Ibnu Hajar Al-Asqalani, Terjemahan Bulughul Maram (Solo: At-Tibyan, 2011), 691. Kitab Jami', Bab Ancaman terhadap akhlak-akhlak tercela Nomer hadist 1409.
} 
prohibition of arrogant, prohibition of pride, development of walking, prohibition of hardening when speak, and ban on rebuking.

\section{E. REFERENCES}

Adawi (al), Syaikh Mustofa. Tarbiyatul Abna', Bagaimana Nabi SAW Mendidik anak. Yogyakarta: Pustaka AL HAURA, 2005.

Ali, Zainuddin. Pendidikan Agama Islam. Jakarta: Bumi Askara, 2015.

Asqalani(al), Al-Hafizh Ibnu Hajar. Terjemahan Bulughul Maram (Solo: At-Tibyan, 2011.

ath-Thahir, Hamid Ahmad. Akhlak islami si buah hati: Pendidikan akhlak ala Nabi. Solo: Pustaka Arofah, 2006.

Baidan, Nashruddin. Metodologi Penafsiran al-Qur'an. Yogyakarta: Pustaka Pelajar, 2000.

Chatib, Munif. Orangtuanya manusia. Bandung: Kaifa, 2013.

Departemen Agama RI. Al-Qur'an dan Terjemahan. Semarang: CV Al WAAH, 1989.

Depdikbud, Kamus Besar Bahasa Indonesia, cet ke 3. Jakarta: Balai Pustaka, 1990.

Hambali, Adang. dkk., "Faktor-Faktor yang Berperan dalam Kebersyukuran (Gratitude) pada Orangtua Anak Berkebutuhan Khusus Perspektif Psikologi Islam”, Psympathic, Jurnal Ilmiah Psikologi Vol. 2, No. 1 Juni 2015.

Hamka. Tafsir Al-Azhar. Jakarta: Gema Insani, 2015.

Hawwa, Sa'id. Kajian Lengkap Penyusian Jiwa, Tazkiyatun Nafs, Intisari Ihya 'Ulumuddin. Jakarta: Pena Pundi Aksara, 2006.

Ilyas, Yunahar. Kuliah Akhlak, cet.1. Yogyakarta: LPPI, 1999.

Mahalli (al), Imam Jalaluddin. Tafsir Jalalain berikut Absabub Nuzul, JIlid 2. Bandung, Sinar Baru Algensindo, 2010.

Mansur. Pendidikan Anak Usia Dini dalam Islam. Yogyakarta: Pustaka Pelajar, 2009.

Mardalis. Metode Penelitian Suatu Pendekatan Proposal. Jakarta: Bumi Aksara, 1999.

Muslim, Al-Imam. Terjemahan Hadis Shahih Muslim, Jilid I, II, III \& IV. Kuala Lumpur: Klang Book Centre, 2007.

Pidarta, Made. Landasan kependidikan, Stimulus Ilmu Pendidikan bercorak Indonesia Edisi III. Jakarta: Rineka Cipta, 2013. 
Pimpinan Pusat Muhammadiyah, Majelis Tarjih. Risalah Islamiyah Bidang Akhlak. Yogyakarta: Suara Muhammadiyah, 2012.

Qorni (al), 'Aidh. La Tahzan, Jangan Bersedih. Jakarta: Qisthi Press, 2004.

Sadily, Hasan. Ensiklopedia. Jakarta: Ikhtiar Baru Van Hoeva, 1980.

Santosa, Harry. Fitrah Based Education. Bekasi: Yayasan Cahaya Mutiara Timur, 2017.

Sulaiman, Abu Amr Ahmad. Panduan Mendidik Anak Muslim Usia Pra Sekolah. Jakarta: Darul Haq, 2013.

Suparman Deden.,"Pembelajaran ibadah shalat dalam perpektif Psikis dan medis, Fakultas Sains dan Teknologi, ISSN 1979-8911, Volume IX No. 2 Juli 2015.

Kusnadi, "Makna Amar Ma'ruf Nahi Munkar Menurut Muhammad Asad Dalam Kitab The Message Of The Qur'an”, Wardah, vol.18, no.2. 2017.

Tualeka, Hamzah. Akhlaq Tasawuf. Surabaya: IAIN Sunan Ampel Press, 2011.

Yunus, Mahmud. kamus Arab- Indonesia. Jakarta: Yayasan penyelenggara penterjemah/ penafsiran al-Qur'an, 1973. 